\title{
Subordinate clauses, switch-reference, and tail-head linkage in Cavineña narratives ${ }^{\star}$
}

\author{
Antoine Guillaume \\ CNRS \& Université Lumière Lyon 2
}

Tail-head linkage is a discourse pattern which consists in repeating, at the beginning of a new sentence, the main verb of the preceding sentence for discourse cohesion. This pattern, which is rarely discussed in general typological work, is widespread in certain areas of the globe, in particular Papua New Guinea. In this paper, I report a case of tail-head linkage in Cavineña, an Amazonian language spoken in the northern lowlands of Bolivia, in which it is manifested by way of three subordinate clause types: two temporal adverbial clauses and a relative clause used adverbially. I also show how the switch-reference system that is associated with certain of these clauses participates in the tail-head linkage system for participant coherence between sentences.

\section{Introduction}

In this paper I describe the discourse use of three types of subordinate clauses in Cavineña, a language spoken by about 1200 speakers in the Amazonian lowlands

*The research presented in this paper is based, for the most part, on first hand data that I collected myself from Cavineña native speakers in traditional communities through about 15 months of fieldwork between 1996 and 2003. The Cavineña people are warmly thanked for their generous hospitality during my stays among them and for their active cooperation while documenting and analyzing their language. About 60 texts and conversations were recorded from a total of about 20 male and female adults ranging from about 20 to 80 years old. The recordings consist in personal life recounts, old time stories, myths, descriptions of local fauna, traditional customs and practices, etc. With the help of informants, the recordings were transcribed and translated (they amount to about 5000 sentences). Another 20 texts were written by Cavineña consultants (about 700 sentences). The corpus was complemented by utterances volunteered or elicited during controlled sessions as well as utterances overheard during participant observation (about 3600 sentences). In addition, I have made use of Cavineña texts collected and published by SIL missionaries Camp and Liccardi (Camp 1982; Camp \& Liccardi 1972; Liccardi 1983, and Tavo Mayo 1977) (about 3500 sentences) and the sentences that illustrate the entries of their (1989) dictionary (about 3000 sentences). The quality of this paper was enhanced thanks to comments by Renée Lambert-Bretière, Françoise Rose and an anonymous reviewer, in addition to comments by Katharina Haude and Rik van Gijn, who acted as editors to the present volume. 
of northern Bolivia. In narratives, these clauses - two temporal adverbial clauses and a relative clause used adverbially - are often placed sentence initially and repeat the main verb/predicate of the preceding sentence, as in the text excerpt in (1); the repeated predicate is in boldface.

(1) a. Amena tume jara-bute-kware ike.

вм then lie-GO_DOWN-REM.PAST 1sG

'Then I lay down (on my raft).'

$(\operatorname{mj} 060)$

b. Jara-bute-tsu betsa-kware.

lie-GO_DOWN-ss swim-REM.PAST

'Having lain down (on my raft), I swam.'

It is a well-known fact that cross-linguistically a major function of adverbial subordinate clauses is discourse cohesion, in particular when placed at the beginning of a sentence. In that position, they can be used as bridges, linking successive sentences or paragraphs by making reference to some information given in the preceding context (Givón 2001:347; Thompson, Longacre \& Hwang 2007:270, 295-297). What is interesting in Cavineña is the fact that very frequently, sentence-initial adverbial (or adverbially-used relative) clauses of the types mentioned above provide the exact replica of the predicate, sometimes even accompanied by its arguments (and/or some other material), a phenomenon that would appear extremely repetitive and stylistically very awkward in many of the languages we are more familiar with.

The verbatim repetition of the verb/predicate of a clause at the beginning of the following sentence has been identified in various languages and language families around the world, to my knowledge all of them located outside Europe. It appears that the first to have written on this pattern are missionary linguists of the Summer Institute of Linguistics working on languages of the Philippines, Papua New Guinea and South America in the 1960s and 1970s (Longacre 1968; Grimes 1972; Thurman 1975, among others). They termed it 'tail-head linkage' - alternative names are 'head-tail linkage', 'recapitulative linkage', 'tail-head recapitulation' or just 'linkage'. To date, the phenomenon of tail-head linkage (henceforth THL) has been best studied in the languages of Papua New Guinea (see for example the synthetic and typological work by de Vries 2005 and many references therein). But THL constructions are also attested in languages and language families from other parts of the world, in particular: ${ }^{1}$

1. I have not conducted any systematic survey of THL in the languages of the world. The following list is only intended to show that THL is a fairly widespread phenomenon crosslinguistically, although poorly discussed in the general linguistic literature. 
- Austronesian languages of the Philippines, sometimes under the same name or under the term 'lexical overlap', depending on whether the construction links paragraphs or sentences, respectively (Thompson, Longacre \& Hwang 2007:273-275);

- Australian languages, under the terms 'backgrounding repetition' (McKay 2008 for Rembarrnga) or 'linked repetition' (Evans 2003 for Bininj Gun-wok, cited by McKay 2008);

- Afroasiatic languages, as in Arabic (Aziz 1988, cited by McKay 2008) and Bedja (Vanhove 2005);

- North-American languages, as in the Pomoan family (Oswald 1976:300);

- South American languages, as in Capanahua from the Panoan family (Loos 1963, cited by Thurman 1975), Kayapó from the Jê family (Stout \& Thomson 1971, cited by Thurman 1975), Tariana from the Arawak family (Aikhenvald 2002:169-171, 2003:576-581), and Wanano from the Tucanoan family (Waltz \& Waltz 1997, cited by Aikhenvald 2002:169-171).

In all these languages, THL is described as a way to connect sentences or clause chains in which the last clause of a paragraph or a chain, i.e. the 'tail clause', is partially or completely repeated in the first clause of the next sentence or chain, i.e. the 'head clause'. This general definition allows for some degree of variation in the formal realization of THL in most of the languages. The most central characteristic of THL is the repetition of at least the verb/predicate of the tail clause. ${ }^{2}$ Nominals (nouns or pronouns) representing the verb/predicate arguments or obliques can be reiterated; occasionally the nominals inserted do not appear in the tail clause. It is also possible that more than one clause be repeated. And sometimes, it is not the last clause that is repeated but another clause of the preceding sentence. In many languages, instead of verbatim repetition of the tail clause verb/ predicate, THL can be realized through the use of a generic verb 'do' or 'be' and a demonstrative ('having done that/so'), pointing back to the event expressed by the tail clause - this is often called 'generic verb linkage' (de Vries 2005:376-377) or 'summary-head linkage' (Thompson, Longacre \& Hwang 2007:274).

2. Note that the term 'tail-head linkage' is sometimes applied to sentence or paragraphlinking devices that do not involve the repetition of verbal material, as with the paragraphinitial anaphoric/linking "connector pronoun" of the Amazonian language Bora, recently discussed by Seifart (2010). It is a matter of debate whether such cases should be included or not as instances of THL. In the present paper, I take the position that they should not. 
THL is mostly used in narratives and procedural texts ${ }^{3}$ and one of its primary functions is maintaining coherence - participant coherence and event coherence ${ }^{4}-$ between subsequent sentences in discourse. ${ }^{5}$ There appear to be different kinds of THL constructions. One of the parameters of variation is the degree of thematic continuity that is found between the sentences that are linked by THL. A majority of (if not all) the languages that manifest THL use this device in contexts of high thematic continuity, that is within individual paragraphs. Some languages have in addition a formally distinct type of THL construction that occurs at major thematic breaks, used between distinct paragraphs. See Grimes (1972:521) and de Vries (2005:377) for examples of languages that display the two types. The former type of THL, which will interest us more in this paper, appears to be used to highlight events that are part of the semantic main event line (MEL). ${ }^{6}$ In the Papuan language Siroi, for example, "THL occurs most frequently in the time-chain of the narrative where it signals the most important events. In fact, by just glancing over the recapitulated clauses of a story you can usually get an accurate impression of the story-line" (van Kleef 1988: 153). In at least some languages, THL also marks completion of the actions involved. In the Papuan language Manambu, "the linkage itself is a way of signaling the fact that one action has finished so that the other one can begin" (Aikhenvald 2008:545). The way THL operates is via an effect of backgrounding/foregrounding. In the Australian language Rembarrnga, "the repeated verb backgrounds the preceding action (already given) as a transition to what is now being introduced, which is foregrounded as the next step in the narrative. [...] It has the effect of putting one event behind and moving on to the next event" (McKay 2008: 10).

Different languages employ THL to different degrees. At one extreme there are languages in which THL is pervasive. In Siroi, for example, "all the main events

3. THL is also attested in other genres in some languages, such as in conversations in some Papuan languages (de Vries 2005:365).

4. In Givón's (2001:328-329) terms, coherence is "the continuity or recurrence of some element(s) across a contiguous span of multi-propositional discourse." Participant and event coherence are part of a wider "tapestry of thematic coherence" that also includes location, temporality, aspectuality, modality, and perspective ('narrative voice').

5. Another typical function of THL, at least in Papuan languages, is processing ease. This function is not relevent for Cavineña, as discussed in $\$ 5$.

6. I am using the concept of MEL in the sense of Payne (1992:379). Drawing on earlier work by Labov \& Waletzky (1967) and Hopper (1979), she defines a clause as belonging to the MEL as having following properties: “(1) it must report an event as actually occurring. The 'event' cannot be a hypothetical one [...] and (2) the actual reporting of the event must advance the action of the narrative along a chronological line". 
of the story are focused on by means of recapitulation. This is done very consistently by most narrators throughout the whole narrative [...]. When THL is not used in the time-chain of the story, something other than the next main event is in focus. This is usually either an event that stands outside the time-chain [as in the setting or summary of the story], or it may be a case of variation of the time-chain [as when introducting new participants or when there is a lapse of time or time standstill between the events]" (van Kleef 1988:152-153). At the other extreme, there are languages where THL is used more sparingly, such as Manambu (Aikhenvald 2008: 545).

THL appears particularly prevalent in certain types of languages. Various authors note the correlation between THL and certain typological characteristics of the languages that have it, in particular that of being polysynthetic and/or favoring null arguments (zero anaphora). De Vries (2005:367) notes that in spontaneous speech, and in particular when expressing sequences of events, speakers of Papuan languages use nominals (nouns or anaphoric pronouns) very infrequently. When they do so, they normally express no more than one nominal per clause, and tend to reserve that one nominal for encoding new information. As a result, these languages do not use nominals to track given, active referents across sentence boundaries; rather this function is taken over by verbs in THL (see also McKay 2008: 10). In her discussion of the Afroasiatic language Bedja, Vanhove (2005) suggests that the phenomenon of repetition could compensate for the lack of 3rd person anaphoric pronouns in the language.

Another interesting observation made by certain authors is the correlation between THL and the presence of a switch-reference system, as found in many Papuan and Amerindian languages. In his discussion of the North-American Pomoan languages, Oswald (1976:300) suggests that verb repetition is used as a way to "continue the discourse [between independent sentences - AG] within the framework of switch-reference" when the switch-reference system is otherwise only available within the domain of the sentence in these languages. In Stirling's (1993: 17, 220-221) terms, "the recapitulation clause allows the switch-reference marking to be carried over from one sentence to the next".

In this paper, I will describe and discuss in detail what I will call THL in Cavineña. I will show that three types of subordinate clauses - two adverbial temporal clause types and one adverbially-used relative clause type - in sentenceinitial position in this language display many (if not most) of the characteristics found in THL constructions in the languages mentioned above.

The paper is organized as follows. Section 2 provides a brief morphosyntactic background to Cavineña clause structure and a general introduction to the main types of subordinate clauses. Section 3 discusses in detail the three types of subordinate clauses that are used in THL: same-subject temporal clause, different-subject 
temporal clause and relative clause. Section 4 addresses the issue of what is exactly repeated from the tail clause and how it is repeated. Section 5 shows that the function of processing ease, typical of Papuan languages, is not relevant in Cavineña THL. The paper ends with a conclusion that summarizes the main features of THL in Cavineña.

\section{Cavineña: Some morphosyntactic background}

\subsection{Main clauses}

Cavineña (verbal) main clauses are headed by a verb that must be inflected by a TAM affix. The arguments are normally expressed either by nominals (NPs or independent pronouns), or by second position pronominal clitics, ${ }^{7}$ or by both at the same time. This latter situation is illustrated by the pair of examples below: in (2) the $\mathrm{O}$ argument 'chicken' is expressed both by the noun takure and the pronominal clitic $=t u$; in (3) the $S$ argument 'jaguar' is expressed both by the noun $i b a$ and the pronominal clitic $=t u$. The arguments are not cross-referenced on the verb/predicate.

(2) Transitive clause

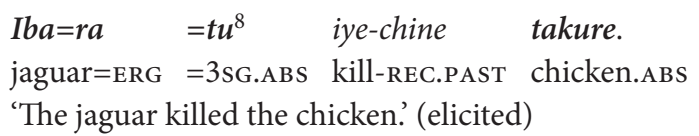

(3) Intransitive clause

[Tuke tupuju $]^{9}=t u \quad$ iba tsajaja-chine.

3sG following $=3$ sG.ABs jaguar.ABs run-REC.PAST

'The jaguar ran behind him.'

(Camp \& Liccardi 1972:33)

As illustrated by the above examples, the morphological encoding of the grammatical functions for both nominals and pronominal clitics patterns according to an ergative/absolutive alignment. The argument in A function is marked by the enclitic $=r a$, as in (2), while the arguments in $\mathrm{O}$ or $\mathrm{S}$ function are left unmarked, as in (2) and (3). In natural discourse, arguments are rarely expressed by overt nominals, unless they refer to newly-introduced referents or in ambiguous contexts;

7. Bound pronouns share the second position with other clitic morphemes coding notions of evidentiality, epistemic modality, discourse status, speaker attitude, etc.

8. Enclitics preceded by a space are second position clitics.

9. Square brackets are used for multiple-word constituents. 
this can be observed in the illustrative text in the appendix to this article. When nominals are used, their ordering is determined by pragmatic factors.

The morphological structure of a verb/predicate, even though it does not include person markers, can be characterized as polysynthetic, due to the fact that (body part) nouns can be incorporated and that a high number of affixes (mostly suffixes) can be used simultaneously to form a verbal word, covering a wide range of functions, such as valency-changing, aspect, associated motion, manner, time of the day, etc.

A number of verbs (e.g. mere 'work', kwatsabiji 'tell a story to') cannot carry any affix and require an auxiliary (light-verb) for this purpose. The auxiliary ju'be' is used when the construction is intransitive, as in (4), while $a$ - 'affect' is used when it is transitive, as in (5).

(4) Junio=ju e-diji=ju mere $j u$ - $k$ ware.

June $=$ LOC NPF-path $=$ LOC work be-REM.PAST

'In June I was working on the road.'

(example volunteered during elicitation session)

(5) Era =mi kwatsabiji a-ya, Antuku...

1sG.ERG $=2$ sg tell_story_to affect-IMPFV Antuku

'I will tell you a story, Antuku...'

$(\operatorname{av} 001)^{10}$

\subsection{Subordinate clauses}

Subordinate clauses of all types differ from main clauses in that their verb carries a marker of dependency, and in that they cannot stand on their own; they form a constituent of a superordinate clause in which they are embedded. According to morphological criteria, Cavineña has two categories of subordinate clauses: (i) non-finite subordinate clauses, whose verb form is stripped from its TAM inflectional affixes, as with the general purpose clause marked by $=i s h u$ in (6), and (ii) finite subordinate clauses, whose verb form must be marked by certain TAM inflectional affixes, as with the reason clause marked by $=t i b u$ in (7).

(6) [Ekwe mama-chi] =bakwe deka=bucha mere

1SG.GEN mother-AFFTN $=$ CONTR man=SIMLR work

ju-kware [ekwana jutu=ishu].

be-REM.PAST 1PL dress=PURP.GNL

'My mother worked like a man so that she could dress us.'

(nk026)

10. Examples followed by a code (2 letters followed by a three-digit number) come from my own corpus of texts. The code corresponds to the place of the sentence in the database. 
The full list of Cavineña subordinate clause types is given in Table 1. (The clauses marked by $-(a) t s u,=j u$ and $=k e$ will be discussed in detail in the remainder of the paper.)

Table 1. Types of subordinate clauses in Cavineña

\begin{tabular}{lllll}
\hline \multicolumn{1}{c}{ non-finite } & & & \multicolumn{2}{c}{ finite } \\
\cline { 1 - 1 } main function & marker & & main function & marker \\
\hline temporal settings & $-(a)$ tsu & & temporal settings & $=j u$ \\
purpose of motion & $=r a$ & & reason & $=$ tibu \\
general purpose & $=i s h u$ & & similarity & $=b u c h a$ \\
cause & $=r a$ & & conditional & $=k e j u a t s u$ \\
immediate anteriority & $=$ wie & & 'thanks to & $=$ ademe \\
& & & concessive & majaka/=amabucha \\
& & relativization & $=k e$ \\
\hline
\end{tabular}

Formally speaking Cavineña does not have complement subordinate clauses nor coordinate clauses per se, although some of the surbordinate clause types of Table 1 are occasionally better translated by complement or coordinate clauses in Spanish or English.

Finite and non-finite subordinate clauses share the additional following properties:

1. The verb of a subordinate clause must come last in the clause; overtly expressed arguments are free to occur in any order before the verb.

2. Subordinate clauses do not contain second position clitics (pronominal clitics and clitics that encode evidentiality, epistemic modality, etc.)

3. The coding of grammatical functions within subordinate clauses follows, like in main clauses, an ergative pattern. With most types of subordinate clauses, we find the exact same case-marking system: ergative case marker $=r a$ on A NPs (suffix -ra on independent pronouns) and absence of case marking on $S$ and O NP.

Having introduced the general characteristics of subordinate clauses, we will now focus on two types of adverbial clauses, the non-finite temporal same-subject clause marked by - (a)tsu and the finite temporal different-subject clause marked $\mathrm{by}=j u$, and on the adverbial use of relative clauses, marked by $=k e$. 


\section{Temporal subordinate clauses}

\subsection{Non-finite temporal same-subject clause ${ }^{11}$}

The first type of subordinate clause that will be discussed has its verb marked by the suffix -(a)tsu. ${ }^{12}$ The semantic relations with the verb of the matrix clause are mainly temporal. Very frequently the events described in the matrix and the subordinate clause occur in a sequence, as in (8). But they can also occur simultaneously, as in (9) and (10). Subordinate clauses marked by -(a)tsu can also be used in generic statements (to specify the circumstances under which a statement holds true), as in (11), or to modify the matrix clause as a manner adverb would, as in (12) and T15. ${ }^{13}$

(8) sequence

Tudya $=$ tuke $=\varnothing \quad$ imeta-tsu mare-kware.

then $=3 \mathrm{sG}=1 \mathrm{sg}$ point_at-ss shoot_at-REM.PAST

'Then I pointed (my rifle) at it (a peccary) and I shot at it.'

(9) simultaneity

Iba $=t u \quad[$ terati=ju ju-ani-tsu $]$

jaguar $=3 \mathrm{sg}$ beam=Loc be-siT-ss

[e-tse jibu-jibu] ju-ani-kware.

NPF-tooth roll_up-REDUP be-SIT-REM.PAST

'The jaguar was sitting on the beam and snarling (rolling his teeth up and down).

(10) simultaneity

Baji-u-si=kwita =tuna ju-wa [iba ba-atsu $]$.

scared-ASF-AUGM=RESTR $=3$ PL be-PERF jaguar see-sS

'They were very scared when they saw the jaguar.' (Camp \& Liccardi 1989:9)

(11) generic statement

[Misi-da tawi-tsu $]$ =yatse tawi ju-ya.

thick-ASF sleep-ss $=1 \mathrm{DL}$ dream be-IMPFV

'When we sleep deeply (lit. when we sleep thick) we dream.'

(Camp \& Liccardi 1989: 81)

11. For a more comprehensive discussion of non-finite temporal same-subject clauses, see Guillaume (2008: Ch. 18).

12. The short form -tsu is used with polysyllabic verbal stems while the long form -atsu is used with monosyllabic stems.

13. T15 refers to the example T15 in the text in the appendix. 
(12) adverbial modification

Pa-bute ike. Ike aje-tsu pa-diru.

HORT.SG-go_down 1sG 1sG walk-ss HORT.SG-go

'I will go down (from the cart). I will go walking.'

(ka456)

Subordinate clauses marked by $-(a) t s u$ have strict co-reference constraints vis-à-vis their matrix clause: their subject is obligatorily co-referential with the subject of the matrix clause. All combinations of subject co-reference are attested (see Guillaume $(2008,2010)$ for more details). One corollary to the same-subject co-reference requirement is that the subject of a clause marked by - $(a) t s u$ is normally omitted. On the other hand, any other clausal constituents, including arguments and obliques, can be expressed and if so, they receive the same marking as they would in a main clause.

Subordinate clauses marked by -(a)tsu (henceforth SS-temporal clauses) are by far the most frequently used type of adverbial subordinate clause (including non-finite and finite adverbial clauses) in Cavineña discourse. ${ }^{14}$

As can be seen, in examples (8) to (12) and T15, SS-temporal clauses can occur at different places vis-à-vis the matrix verb (before or after) and vis-à-vis other clausal constituents within the sentence. It is not clear whether specific positions trigger specific semantic readings; this issue needs more work. In any case, in narratives, there is a very strong correlation between sentence-initial position and THL as introduced in $\$ 1 .{ }^{15}$ In this position, very frequently (although not obligatorily), SS-temporal clauses repeat the main verb/predicate of the (near) immediately preceding sentence, sometimes accompanied by its arguments (and other material), as in sentences c., e. and f. of the following text excerpt. The repeated material is in boldface.
a. Ani-kware =tu [peadya ekwita Alberto bakani]. be-REM.PAST $=3 \mathrm{sg}$ one man Alberto named 'There was a man named Alberto.'
b. Tu kwa-kware [mara akwi sare=ra]. 3SG go-REM.PAST mara_tree tree look_for=PURP.MOT 'He went (in the jungle) looking for mara wood (for selling).'
c. Kwa-atsu =tu kuji ju-ti-kware ekwita. go-ss =3sG get_lost be-Go-REM.PAST man 'While going, the man got lost.'

\footnotetext{
14. In an illustrative text provided in Guillaume (2008:773-798), for example, subordinate clauses marked by -(a)tsu are found in $17 \%$ of the sentences ( 26 occurrences out of 153 sentences). And in the text provided in the appendix to this paper, subordinate clauses marked by -(a)tsu are found in $23 \%$ of the sentences (12 occurrences out of 51 sentences).

15. In this paper, I will only discuss THL in narratives, although it is also used in other genres such as procedural texts and conversations.
} 
d. [Kimisha wekaka meta beta jadya tawi-wa=ke] =tu three day night two and sleep-PERF=LIG $=3 \mathrm{sG}$ $e-b a k w a=k e=r a$ [datse iwa-tsu $]$ sare-ti-kware. 3-child=3=ERG FRUST wait_for-ss look_for-GO-REM.PAST '(The man) having gotten lost (lit. slept) three days and two nights, his child, waiting in vain for him, went looking for him.'

(hp004)

e. Sare-ti-tsu =tu e-tata=ke chamakama dadi-kware. look_for-GO-ss $=3 \mathrm{sg}$ 3-father=3 finally find-REM.PAST 'Going looking for him, he finally found his father.'

f. Dadi-tsu =tu e-bakwa=ke=ra beti-kware. find-ss $=3 \mathrm{sg} \quad 3$-child $=3=$ ERG bring-REM.PAST 'Finding him, the child brought him back (home)'.

Other instances of THL involving SS-temporal clauses can be seen in seven clauses of the text in the appendix: T4, T7, T11, T25, T26, T34 and T47.

Note that the correlation between THL and sentence-initial position is not perfect. That is, sentence-initial position does not obligatorily imply a THL construction, as in (11), for example, which is a generic statement, therefore not part of a narrative story-line. Conversely, although this is rather rare, a SS-temporal clause in a different position might also be involved in a THL construction, as in T7, for example.

The discourse effect of this THL construction in Cavineña is very similar to that noted for other languages above $(\$ 1)$, namely one of foregrounding the most important events of the semantic main event line. If we consider Payne's (1992) criteria (cf. Footnote 6), we can observe that the clauses involved in THL express events are actually occurring, not hypothetical (Payne's property 1 ) and that they express events that advance the action of the narrative along a chronological line (Payne's property 2). Thus, in the short text in (13), we can see that THL links and highlights the clauses that express the important milestones/steps of the story, "the man went" and "the man got lost" in c., "his son went looking for him" and "his son found him" in e., and "his son found him" and "his son brought him back (home)" in $\mathrm{f}$. In fact, in each of these pairs, the event expressed by the second clause cannot occur if the event of the first clause has not occurred. It also gives the feeling that when THL is used, that is when a sentence begins with a subordinate clause that repeats the main verb of the previous sentence, one expects the verb of the second sentence to express a new significant event, with important bearings for the remainder of the story, and one is invited to pay more attention. By contrast, we can observe that at least in this short text the clauses that are not repeated in THL constructions are mainly side comments/clarifications, such as "there was a man named Alberto" in a., "(he went) looking for mara wood" in b., "he slept three days and two nights" in d. and g. and "his child waited in vain" in d. 
A noteworthy aspect of SS THL constructions is that they have the effect of carrying the same-subject constraint of SS-temporal clauses across sentence boundaries. This is a logical consequence of the fact that the subordinate clause verb is the same as the main verb of the preceding sentence and that it must have the same subject as the main verb of the sentence it belongs to. Certain authors such as Oswalt (1976) have suggested that this phenomenon, which helps tracking participant reference between different sentences, could be a possible motivation for a language to develop a THL system (see $\$ 1$ ). As we will see in the next section, Cavineña allows for a second type of subordinate clauses to enter THL constructions, different-subject temporal clauses, which function in complementary distribution with SS-temporal clauses for linking two sentences whose main verbs have a different subject.

\subsection{Finite temporal different-subject clause $\mathrm{e}^{16}$}

The second type of subordinate clause to be discussed has its verb marked by the clitic $=j u$. Similarly to SS-temporal clauses, this type of clause is extremely frequent in natural discourse. ${ }^{17}$ In addition, their main function is also very similar, namely to encode temporal settings for the event expressed by the matrix clause. There are however two main formal differences between the two types of clauses. First, subordinate clauses marked by $=j u$ imply a subject switch: the referent of the subordinate clause subject cannot be co-referential with the subject of the matrix clause (see Guillaume $(2008,2010)$ for more details). Second, subordinate clauses marked by $=j u$ have overt marking for their relative temporal relation to the matrix clause. Being of the finite type, the verb of a clause marked by $=j u$ must bear inflectional affixes. Specifically, this type of clause usually contains the aspectual inflectional markers - wa 'PERF' or - ya 'IMPFV', the first one implying sequence, the second simultaneity. These properties are illustrated in the following examples.

(14) sequence

$$
\begin{aligned}
& \text { A- } k \text { ware=dya =tuna tee. Rarara- } w a=j u=\text { tuna tucha- } k \text { ware. } \\
& \text { affect-REM.PAST=FOC }=3 \mathrm{PL} \text { garden dry-PERF=DS =3PL burn-REM.PAST } \\
& \text { 'They cleared a garden. When it (the garden) had dried, they burned it.' }
\end{aligned}
$$

\footnotetext{
16. For a more comprehensive discussion of finite temporal different-subject clauses, see Guillaume (2008: Ch. 19).

17. For example, in the text provided in the appendix, this type of clause is found in $17 \%$ of the sentences ( 9 occurrences out of 51 sentences).
} 
(15) simultaneity

Chamakama apupu-ya=ju ju-diru-kware.

finally darken-IMPFV=DS be-GO-REM.PAST

'Finally, when it was getting dark, I arrived.'

Subordinate clauses marked by $=j u$ can also be used in generic statements:

(16) generic statement

$$
\begin{array}{lll}
{[\mathrm{Dii}=\mathrm{ra}} & \text { karu- } y \boldsymbol{a}=\mathrm{ju}] & \text { pude-na-ya. } \\
\text { mosquito=ERG } & \text { bite-IMPFV=DS } & \text { red-vBLZ-IMPFV } \\
\text { 'When a mosquito bites me, I become red.' }
\end{array}
$$

Similarly to SS-temporal clauses, subordinate clauses marked by $=j u$ (henceforth DS-temporal clauses) do not have a strict position in the sentence. They occur very frequently before the matrix verb, as in the preceding examples, but they can also be found after the matrix verb:

$$
\begin{aligned}
& \text { Tatse =bakwe jekutana=dya } \\
& \text { 3DL =CONTR be_scarded=FOC } \\
& \text { [ekwanara jadya kwatsabi } a-y a=j u] . \\
& \text { 1PL.ERG thus tell_story_to affect-IMPFV=DS } \\
& \text { 'They were scared when we told them the story'. }
\end{aligned}
$$

The functional similarity between the two types of temporal subordinate clauses, those marked by - $(a) t s u$ and those marked by $=j u$, and the fact that they mainly differ in their specification for having a same or different subject from their matrix clause makes the pair look very similar to a switch-reference system. This impression is reinforced by the fact that DS-temporal clauses can also be used in THL constructions in narratives, in complementary distribution with SS-temporal clauses, when there is a subject switch between the two sentences, as in the following text excerpt - the full text is provided in Guillaume (2008: 796-798).

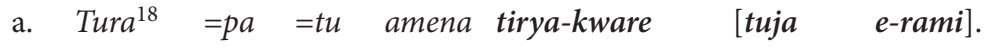

$$
\begin{aligned}
& \text { 3SG.ERG }=\text { REP }=3 \mathrm{SG} \text { BM finish-REM.PAST 3sG.GEN NPF-flesh } \\
& \text { 'They (the giant mosquitoes) ate all (lit. finished) her flesh.' (mm011) }
\end{aligned}
$$

18. Occasionally 3 rd person singular pronouns can refer to plural referents; see Guillaume (2008: 604-605) for a discussion. 


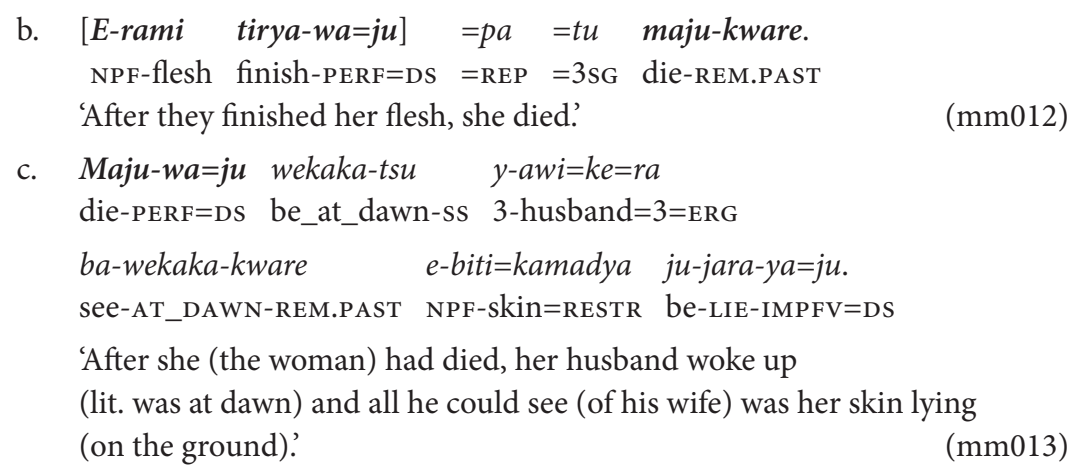

Additional examples of DS-temporal clauses involved in THL can be found in clauses T17, T36 and T43 of the text in the appendix. ${ }^{19}$

In THL constructions, DS-temporal clauses tend to occur sentence initially. Note that the correlation is again not perfect. In particular, not all sentence-initial DS-temporal clauses are involved in THL, as in (14) or T37, for example, where we can see that the DS-temporal clauses does not repeat the predicate or anything from the preceding sentence, or in (16), which is a generic statement.

As a logical consequence of the different-subject constraint that characterizes DS-temporal clauses, and of the fact that they repeat the main verb of the preceding sentence, the main verbs of two subsequent sentences linked by a THL construction that involve this type of clause must have different subjects. In other words, the different-subject constraint is carried across sentence boundaries. As such, there is a complementary distribution between SS-temporal and DS-temporal clauses in THL. The complementary use of the two clause types is even more evident considering that DS THL constructions also have a very similar discourse effect, namely that of keeping track of the semantic main event line. In all the examples cited, the clauses involved in THL express events that are actually occurring, not hypothetical (Payne's property 1 ) and express events that advance the action of the narrative along a chronological line (Payne's property 2 ). This can be verified by looking at the SS THL and DS THL constructions in the text in the appendix. SS THL in T4 highlights the transition between the two main line events "the man went" and "the man met a caiman", in T11 the transition between "the man went (again)" and "the man killed all that he wanted to kill". Then DS THL in T17 draws attention to the move from "the man was standing very worried" to a new important event

19. The text in the appendix includes five additional instances of subordinate clauses marked by $=j u$ involved in THL constructions, T32, T35, T40, T42 and T45. These are used for recapitulating direct speech quotations. Their formal realization is slightly different from the THL constructions discussed so far. They are dealt with in $\$ 4$. 
involving a different subject, "a big caiman appeared". In T25, we have another instance of SS THL, linking "the caiman put the man up (on his back)" and "the caiman carried the man to the middle of the lake" and in T26 the link between "the caiman carried the man to the middle of the lake" and "the caiman conducted him according to his own will". In T36 DS THL highlights the transition between "the man became very worried" and "a dog arrived", and in T43 between "the caiman was moving closer" and "the dog talked to him again". Finally, in T47, a last SS THL construction links the last two main events of the story, "the man jumped" and "the man went away".

THL constructions in Cavineña operate within stretches of text of relatively high thematic continuity, in terms of participants - even though there can be a topic/subject switch -, location, temporality and events (see Footnote 4 for a definition of thematic coherence). In other words, THL in Cavineña is probably a device that operates within the paragraph rather than between different paragraphs.

In the next section, we will discuss one last type of subordinate clause that is found in THL constructions, relative clauses.

\subsection{Adverbially-used relative clauses ${ }^{20}$}

The third type of clause to be discussed is of the finite type - its verb must bear inflectional affixes - and is marked by the clitic $=k e$. This clause type is typically used to modify the head of an NP, as a relative clause, whether restrictive, as in (19), T1 and T11, or non-restrictive, as in (20).

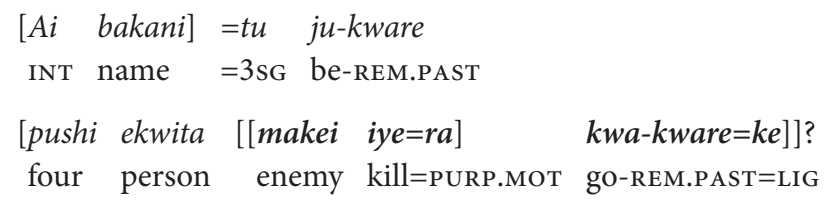

'What are the names of the four men who went to kill the enemies?'

(Tavo Mayo 1977:73)

(20) Tume =tukwe ani-kware [bina [ike susu-ti-ya=ke]]. then =COUNT.EVID sit-REM.PAST bat $1 \mathrm{sg}$ suck-GO-IMPFV=LIG 'There was a (vampire) bat that was going to suck me (during my sleep)'. (bi016)

20. For a more comprehensive discussion of relative clauses, see Guillaume (2008: \$13.6 and Ch. 19). 
Further characteristics of Cavineña RCs used as NP modifiers - not discussed here - are (i) that they do not require an overt NP head, (ii) that their position vis-à-vis the head (if overtly expressed) is flexible (postposed or preposed), (iii) that they can be internally headed.

RCs can also function as temporal adverbial clauses, in which case they provide temporal settings for the whole matrix clause, rather than specifications of a particular NP head, as in (21), which is hardly translatable by a relative clause in English (or Spanish for that matter).

$$
\begin{aligned}
& \text { [Juye kanajara-sha-ya=ke] =yatse tawi-ya. } \\
& \text { ox rest-CAUS-IMPFV=LIG =1DL sleep-IMPFV } \\
& \text { 'While we (dl) are letting the oxen rest, we (dl) will sleep } \\
& \text { (lit. we, who are letting the oxen rest, will sleep).' }
\end{aligned}
$$

When used as temporal adverbial clauses, RCs make use of the two aspectual inflectional markers - wa 'PERF' and $-y a$ 'IMPFV' for encoding sequence versus simultaneity, respectively, between the RC and the matrix clause, in a way very similar to that of these suffixes in DS-temporal clauses (\$3.2). This can be seen by comparing (21), with a simultaneous relation, with (22), with a sequential relation (see also (13d) above).

$$
\begin{aligned}
& {[\text { Rekwana=keja ju-neni-wa=ke]}=\text { taa }} \\
& \text { this_stuff_here=LOC.GNL be-RANDOM-PERF=LIG =EMPH } \\
& {[\text { ekwe mamita }] \text { maju-wa. }} \\
& \text { 1sG.GEN mommy die-PERF } \\
& \text { 'After having been around these places my mother died } \\
& \text { (lit. my mother, who had been around this stuff here, died).' }
\end{aligned}
$$

Strictly speaking, RCs used adverbially do not display any obvious differences from those used as regular RCs. They are still regularly case-marked if the common argument is in A function, ${ }^{21}$ as in (23), or in an oblique function.

$$
\begin{aligned}
& \text { Iwa =tuna bidubidu a-ya [ebarukwe neti-ya=ra]. } \\
& \text { tail =3PL wag affect-IMPFV top stand-IMPFV=ERG } \\
& \text { 'They (my dogs) were wagging their tails, as they were standing up } \\
& \text { (lit. they, who were standing up, were wagging their tails).' }
\end{aligned}
$$

21. Note that the ligature marker $=k e$ is regularly deleted if it is followed by a case marker, explaining why it does not appear in this example. 
The position of RCs used adverbially vis-à-vis the matrix clause is again not rigid. Their preferred position is before the matrix clause verb, as in (21) and (22), but they are also found after, as in (24). Moreover, when placed before the verb, they need not occur sentence initially, as seen in (25) and T12.

$$
\begin{aligned}
& \text { a. Tsajaja-ni-kware =shana } e \text {-tata }=k e \\
& \text { run-RANDOM-REM.PAST }=\text { PITY } 3 \text {-father }=3 \\
& \text { [e-bakwa=ke dadi-ya=ke=ama]. } \\
& 3 \text {-child }=3 \text { find-IMPFV }=\text { LIG }=\text { NEG }
\end{aligned}
$$

'The poor father searched for his child everywhere

(lit. ran in many different places), unable to find him

(lit. the father, who could not find his child, ran).'

(25) Tume $=p a$ =tu tawi-ya=ke

then $=\mathrm{REP}=3 \mathrm{SG}$ sleep-IMPFV $=$ LIG

jucha a-ta-karama ju-kware.

have_sex_with affect-PASS-DESID.NEG be-REM.PAST

'When they (the woman and her husband) were sleeping (in the mosquito net), she refused to have sex.'

RCs used adverbially in sentence-initial position are the third type of subordinate clauses that can be used in THL constructions in narratives, as in the following text excerpts.

(26) a. Tume nubi-eti-nuka-wa.

then enter-COME-REITR-PERF

'I came back inside (the house).'

b. Nubi-eti-ya=ra =tuke $=\varnothing$ baka-nuka-wa waka=bucha. enter-COME-IMPFV=ERG $=3 \mathrm{SG} \quad=1 \mathrm{SG}$ hear-REITR-PERF COW=SIMLR 'As I was coming back inside (lit. I, who was coming back), I heard something again that seemed like a cow.'

(27) a. Jara-diru $=p a$ ekatse.

lie-GO $=$ REP 3DL

'They (dl) lay down.'

b. 'At that time there was no mosquito net nor anything to sleep conveniently'.

c. 'I don't know how they would sleep.'

$(\mathrm{hm} 050)$

d. Tume jara-ya=ke=dya =pa =tu amena tawi-wa.

then lie-IMPFV $=\mathrm{LIG}=\mathrm{FOC}=\mathrm{REP}=3 \mathrm{SG}$ вM sleep-PERF

'So as they were lying down (lit. they, who were lying down), they slept.' 
e. Tawi-ya=ke=dya =pa =tu mari-tere- $k w a r e$.

sleep-IMPFV $=$ LIG $=$ FOC $=$ REP $=3 \mathrm{sG}$ roar-COMP-REM.PAST

'While they were sleeping (lit. they, who slept), they moaned.' (hm052)

(28) a. Tume [eweebari weni-da=ekatse=ra] ara-ya.

then teenager vigorous- $\mathrm{ASF}=\mathrm{DL}=\mathrm{ERG}$ eat-IMPFV

'These two vigorous teenagers were eating it (a raw wild turkey).' (hm091)

b. Tume ara-ya=ra =pa =tuja =tu

then eat-IMPFV $=$ ERG $=$ REP $=3 \mathrm{sG} . \mathrm{DAT}=3 \mathrm{SG}$

ba-kware sawa-da.

see-REM.PAST green/blue-ASF

'As they were eating it (lit. they, who were eating it), they found out that it was raw (lit. they saw it green/blue).'

(hm092)

See also an instance in T29.

The correlation between sentence-initial adverbial RCs and THL, although very high, is again not perfect. In (29b), for example, we can see that the sentenceinitial adverbial RC does not repeat the predicate of the preceding sentence (29a).

a. Ju-eti-chine $=d y a \quad$ ekwana.

be-COME-REC.PAST=FOC $1 \mathrm{PL}$

'We arrived (by plane, in Tumichucua's airstrip).'

(Camp 1982: 121, sentence no. 98)

b. [Tume avion=ju=ke kwinana-ya=ke] =tu [señora Ana=ra]

there plane $=$ LOC $=$ LIG emerge $-\mathrm{IMPVF}=\mathrm{LIG}=3 \mathrm{sG}$ lady Ana $=\mathrm{ERG}$

[señorita Milli] iyuka=tsewe a-chine iyuka=ju.

lady Mili head=ASSOC affect-REC.PAST head=LOC

'When she got out of the plane, Mrs Ana bumped Mrs Milli, with her head.'

(Camp 1982: 121, sentence no. 99)

A similar example can be observed with the sentence-initial adverbial RC in (13d).

The discourse function of RC THL constructions does not appear to be any different from that of the SS THL and DS THL constructions discussed earlier: they are used to keep track of the semantic main event line. They involve events that are actually occurring, not hypothetical (Payne's property 1) and that advance the action of the narrative along a chronological line (Payne's property 2 ). The RC THL of T29 in the appendix text, for example, highlights the move from the two significant events, 'an ox went to drink' and 'the caiman talk to him (the ox)'. 
In terms of reference tracking, RC THL constructions function on a rather different basis than SS and DS THL constructions, since the subject of the clause recapitulated in the $\mathrm{RC}$ clause can be either co-referential or non co-referential with the subject of the matrix clause. For example, the subjects are co-referential in (26b), where RC S = Matrix A, (27d) and (27e), where RC S = Matrix S, and (28b), where RC A = Matrix A. And the subjects are non co-referential in $\mathrm{T} 29$, where $\mathrm{RC} S=$ Matrix $\mathrm{O} \neq \mathrm{A}$. It is not clear why the speaker chose RC THL constructions in these examples, rather than SS or DS THL constructions. This issue needs more work. ${ }^{22}$

\section{Variation on a theme: Formal variants of THL in Cavineña}

A characteristic of THL constructions that is mentioned in most studies of this phenomenon in languages around the world is that they allow for some variation in what is exactly repeated from the tail clause and how it is repeated ( $\$ 1)$. In this section, we will look at this aspect in Cavineña THL.

Cavineña THL always involves the repetition of at least a verbal root. In some cases, there is repetition of some (non-inflectional) affixes, as with the directional/ motion suffixes -bute 'GO_DOWN' in (1b), - $t i$ 'GO' in (13e) and -eti 'COME' in (26b).

The recapitulative clause can repeat one or more arguments, as in (30b), with the repetition of the $3 \mathrm{rd}$ person plural pronoun in A function tunara '3PL.ERG' and the locative phrase $e$-tare $=j u$ 'NPF-house=LOC', and in (31), with the repetition of the $\mathrm{S}$ argument salón 'rifle'.
a. Tudya amena =tunara $=\varnothing \quad$ e-tare $=j u \quad$ duju- $k$ ware. then $\mathrm{BM}=3 \mathrm{PL} . \mathrm{ERG}=1 \mathrm{SG}$ NPF-house $=$ LOC transport-REM.PAST 'Then they took me home.'
(mg029)
b. [Tunara e-tare $=j u \quad d u j u-w a=j u]$
3PL.ERG NPF-house $=$ LOC transport-PERF=DS
ike amena ka-ba-ti-diru-kware...
1SG BM REF-See-REF-GO-REM.PAST
'After they had taken me home, I recovered consciousness (lit. I saw myself).'

22. In fact, the problem is not specific to THL constructions but to all adverbially-used RCs, whether in THL constructions or not. For instance, in the non-THL examples of adverbiallyused RCs cited above, (21) to (25), it is not clear why SS clauses are not used instead. 
(31) a. Tume =tu salón pututa-wa=ama.

then $=3 \mathrm{sg}$ rifle burst-PERF=NEG

'But the rifle didn't work (lit. burst).'

b. [Salón pututa-ya=ama=ju] =tu kwa-nuka-wa [peya e-tare=ju].

rifle burst-IMPFV $=$ NEG $=$ DS $=3 \mathrm{SG}$ go-REITR-PERF other NPF-house $=$ LOC 'As the rifle was not working, he (Lucio) went to another house (to ask for another rifle).'

The arguments can be repeated identically as they appear in the tail clause, as in the examples above, or they can be referred to by an anaphoric word, such as a demonstrative, as in (34c) further below. Certain particles can be repeated, as with the negative enclitic $=a m a$ in (31). There are cases of repetition of a full complex sentence containing a main clause and an embedded purpose of motion clause, as in T4. There are also cases of repetition of a copula clause (i.e. of the copula verb and its copula complement), as in T36.

A variant of THL involves the anaphoric manner demonstrative particle jadya 'thus, so'. This phenomenon is reminiscent of what is called "generic verb linkage" in Papuan languages $(\$ 1)$, although it is used in a slightly different way in Cavineña. The most frequent use of the particle jadya in THL is in constructions that refer back to quotation of direct speech, thoughts or expression of feeling. As such, the particle jadya refers to the quoted material while the act of quoting is referred to by either ju- 'be, say', or $a$ - 'affect', depending on whether the act of quoting is intransitive (not involving a clearly identified addressee), as in (32), or transitive (involving a clearly identified addressee), as in (33).

a. "Pa-diru ike!"

HORT.SG-go 1sG

“'I’m going!” (I said to myself).'＜noBreak>（Liccardi 1983:56, sentence no. 41)

b. [Jadya ju-atsu] diru-chine tsajaja=kama.

thus be-ss go-REC.PAST run=ONLY

'After I said so, I went back running all the way'

(Liccardi 1983:56, sentence no. 42)

(33) a. "Rewa ani-kwe!"

here sit-IMP

“Sit (down) here! (my mother told my older sister)' (Tavo Mayo 1977:28)

b. $\left[\begin{array}{ll}\text { Jadya } & a-a t s u\end{array}\right]$ =tura =ekwe e-nasi shana-kware.

thus affect-ss $=3$ SG.ERG $=1$ sG.DAT 1 -older_sister leave-REM.PAST

'After telling her so, she left my older sister.'

(Tavo Mayo 1977:28) 
Note that there is nothing fundamentally specific to this construction. The verbs $j u$ - and $a$ - can be used to mean 'say' (intransitive) and 'tell' (transitive) - see an example in T32. And jadya can be used in non-THL constructions to mean 'thus'. And in discourse, the function is that of highlighting and maintaining coherence between subsequent direct speech (or thought/feeling) quotation events with different speakers - as in T32 between "the caiman said so" and "the ox answered" and in T40 between "the caiman said so" and "the dog told him" - or between a direct speech (or thought/feeling) quotation event and another event - as in T17 between "he was thinking so" and "a big caiman appeared", in T23 between "the caiman said so" and "the caiman made the man sit on top of him", in T35 between "the caiman told the man so" and "the man became very worried", in T42 between "the dog was saying so" and "the caiman moved closer", and in T45 between "the dog told the caiman so" and "the caiman kept going closer".

Unlike many other languages that manifest THL, Cavineña appears to restrict the use of 'thus' + 'be/affect' constructions for the recapitulation of quotation events, not for the recapitulation of other kinds of events. In the latter case at least the full form of the verb/predicate is normally repeated. Only a few exceptions could be found in the corpus, as in T28, where jadya ju-ya=ju 'as he was doing so' does not refer to an act of quotation but to the preceding event 'he did not carry him properly'.

There is finally one last variant of THL that, for exhaustiveness, and because it is very frequently used in text, should be mentioned, although it will not be discussed in detail here. In this variant, the recapitulative subordinate clause includes, in the following order, the verb/predicate of the preceding sentence in a non-finite form, the particle jadya 'thus' and an auxiliary (light verb) for carrying the subordinating marker (whether $-(a) t s u,=j u$ or $=k e$ ). An example of an intransitive construction is given in (34b); note that this text excerpt also includes a regular THL construction in c. (i.e. without jadya and an auxiliary). An example of a transitive construction can be found in T26 of the appendix text.
a. $J i-d a=d y a \quad=d i$
gOod-ASF=FOC $=$ STRG.EMPH REF-cross-REF-REM.PAST
'I crossed well.'
ka-rike-ti-kware.
$(\operatorname{mj} 089)$
b. [Ka-rike-ti jadya ju-atsu $]$ tapeke=piji ara-kware.
REF-cross-REF thus be-ss trip_food=DIM eat-REM.PAST
'After crossing, I ate the food.'
c. [Tumeke ara-tsu] era ijeti peta-ya. that eat-ss 1sG.ERg sun look_at-IMPFV
'After eating that (food), I looked at the sun (to know what time it was)'. 
Functionally, I have not been able to detect any clear differences between THL construction with jadya + auxiliary and THL constructions without jadya + auxiliary. In examples like (34), jadya seems to refer back to the manner in which the action is carried out, namely 'well' in this example, but there are other cases in which the verb action does not appear to be carried out according to any particular manner, as in T26, for example. This issue is tied to the more general issue of complex predicate constructions in Cavineña, in which a lexical verb is used in a frame involving one of the two (intransitive and transitive) auxiliaries. The functional/semantic effects of these complex predicates, which are also found in main clauses, are not fully understood yet. For more discussion, see Guillaume (2008: Ch. 10 , in particular $\$ 10.5)$.

\section{Cavineña THL and processing ease}

THL constructions in Papuan language often display specific intonation contours associated with head clauses, such as a markedly slowed down pronunciation, a final rise towards the end of the head clause, and the insertion of pause markers or discourse conjunctions with pause contours right after the head clause. These particular intonational contours are said to play a role in the area of processing ease in languages that often haveverylong narrative sentences (or clausechains) and require a "break" between these long sentences (or clause chains), for the listener to process the information just heard, and for the speaker to formulate his next chain (de Vries 2005:363-364, 378). ${ }^{23}$

THL constructions in Cavineña, whether realized by same-subject clauses (\$3.1), different-subject clauses $(\$ 3.2)$, or relative clauses $(\$ 3.3)$, do not manifest any particular intonational properties. Although I have not conducted any detailed study on Cavineña prosody, as far as I can say, these three types of clauses have the same intonation characteristics whether or not there are used in THL constructions. ${ }^{24}$ In any case, they do not display any of the intonational characteristics of Papuan head clauses mentioned above (slower speech, rising contour or pause insertion).

23. I thank an anonymous reviewer for pointing this aspect of THL in Papuan languages to me.

24. For general information on accent and intonation in Cavineña, see Guillaume (2008: Ch. 2, \$\$2.7-2.8). 
The absence of any particular intonational contour in Cavineña THL construction is congruent with the fact that this language is neither a clause-chaining language, nor a language in which sentences are particularly long. The need for processing ease is therefore not as relevant in this language as it can be in Papuan languages.

\section{Conclusions}

THL in Cavineña is instantiated by three subordinate clause types: SS-temporal clauses, DS-temporal clauses, and adverbially-used RCs. When these clauses are used in THL constructions, they are normally placed in sentence-initial position. THL is widely attested in narratives and more specifically at particular points in narratives where the story line is moving ahead. Its main function has to do with maintaining participant and event coherence between subsequent sentences in discourse. By repeating, at the beginning of a new sentence, the main verb of the preceding sentence, THL constructions act as inter-sentential bridges. They have the effect of backgrounding an important event, expressed in the preceding sentence, and of foregrounding a new important event, expressed in the following sentence. By repeating the same verb, THL allows the hearer to keep track in a very precise way of the semantic main event line (the backbone of the narrative), in terms of participants and events. Of note is the phenomenon by which THL carries the switch-reference tracking of participants across sentence boundaries.

Cavineña THL constructions presents most of the formal and functional characteristics generally found in Papuan and other THL languages. Moreover, if we look at the general typological characteristics of Cavineña and those of other languages with THL, we find that we are dealing with the same type of languages, namely polysynthetic and argument-dropping. There is possibly one property that distinguishes Cavineña THL constructions from those in other THL languages. This is found in "generic verb linkage" (particle jadya 'thus' + auxiliary). As we saw, in Cavineña "generic verb linkage" is restricted to the recapitulation of quotation events, while in many other THL languages, this kind of construction is used more generally for referring back to any event expressed in the tail clause.

Another difference between Cavineña THL constructions and those in other languages, in particular Papuan languages, is the absence of particular intonational properties. In Papuan languages, these play an important function in the processing ease of very long clause chains/paragraphs. The lack of 
such types of clause chains/paragraphs in Cavineña is a possible motivation for explaining the absence of particular intonational properties in THL in this language.

\section{Abbreviations}

$\begin{array}{llll}\text { [ ] } & \text { multiple-word constituent } & \text { itr. } & \text { intransitive } \\ \text { 1,2,3 } & \text { 1st, 2nd, 3rd person } & \text { LIG } & \text { ligature } \\ \text { A } & \text { transitive subject } & \text { LOC } & \text { locative } \\ \text { ABIL } & \text { abilitative } & \text { LOC.GNL } & \text { general locative } \\ \text { ABS } & \text { absolutive } & \text { NEG } & \text { negative } \\ \text { AFFTN } & \text { affection } & \text { NMLZ } & \text { nominalizer } \\ \text { ANT } & \text { (immediate) anteriority } & \text { NPF } & \text { noun prefix } \\ \text { ASF } & \text { adjective suffix } & \text { O } & \text { object } \\ \text { ASSOC } & \text { associative } & \text { PASS } & \text { passive } \\ \text { AUGM } & \text { augmentative } & \text { PERF } & \text { perfect } \\ \text { BM } & \text { boundary marker } & \text { PL/pl } & \text { plural } \\ \text { CAUS } & \text { causative } & \text { POT } & \text { potential } \\ \text { CAUS.INVLT } & \text { causative of involvement } & \text { PURP.GNL } & \text { general purpose } \\ \text { COMP } & \text { completive } & \text { PURP.MOT } & \text { purpose of motion } \\ \text { CONTR } & \text { contrastive } & \text { RC } & \text { relative clause } \\ \text { CONT.EVID } & \text { contrary to evidence } & \text { REC.PAST } & \text { recent past } \\ \text { DAT } & \text { dative } & \text { REDUP } & \text { reduplication } \\ \text { DESID } & \text { desiderative } & \text { REF } & \text { reflexive } \\ \text { DIM } & \text { diminutive } & \text { REITR } & \text { reiterative } \\ \text { DL/dl } & \text { dual } & \text { REM.PAST } & \text { remote past } \\ \text { DS } & \text { different subject } & \text { REP } & \text { reportative } \\ \text { EMPH } & \text { emphatic } & \text { RESTR } & \text { restrictive } \\ \text { ERG } & \text { ergative } & \text { S } & \text { intransitive subject } \\ \text { FILL } & \text { (lexical) filler } & \text { SG } & \text { singular } \\ \text { FOC } & \text { focus } & \text { SIMLR } & \text { similarity } \\ \text { FRUST } & \text { frustrative } & \text { SS } & \text { same subject } \\ \text { GEN } & \text { genitive } & \text { STRG.EMPH } & \text { strong emphasis } \\ \text { HORT } & \text { hortative } & \text { T } & \text { text in the appendix } \\ \text { IMP } & \text { imperative } & \text { THL } & \text { tail-head linkage } \\ \text { IMPFV } & \text { imperfective } & \text { UNCERT } & \text { uncertain } \\ \text { INT } & \text { interrogative } & \text { VBLZ } & \text { verbalizer } \\ & & & \end{array}$




\section{References}

Aikhenvald, Alexandra Y. 2002. Language Contact in Amazonia. Oxford: OUP.

Aikhenvald, Alexandra Y. 2003. A Grammar of Tariana, from Northwest Amazonia. Cambridge: CUP.

Aikhenvald, Alexandra Y. 2008. The Manambu Language, from East Sepik, Papua New Guinea. Oxford: OUP.

Aziz, Yowell Y. 1988. Cohesion in spoken Arabic texts. In Pragmatics, Discourse and Text: Some Systemically-inspired Approaches, Erich H. Steiner \& Robert Veltman (eds), 148-157. London: Pinter.

Camp, Elizabeth L. 1982. Referentes de movimiento y ubicación en el discurso narrativo en cavineña. Revista Latinoamericana de Estudios Etnolingüísticos 2: 81-122.

Camp, Elizabeth L. \& Liccardi, Millicent R. 1972. Quiero contarles unos casos del beni; Castellano y Cavineña. Cochabamba: Instituto Lingüístico de Verano.

Camp, Elizabeth L. \& Liccardi, Millicent R. 1989. Diccionario Cavineña-Castellano CastellanoCavineña con Bosquejo de la Gramática Cavineña. Dallas TX: Summer Institute of Linguistics.

Evans, Nicholas. 2003. Bininj gun-wok: A pan-dialectal Grammar of Mayali, Kunwinjku and Kune. Camberra: Pacific Linguistics.

Givón, T. 2001. Syntax. An Introduction, Vol. 2. Amsterdam: John Benjamins.

Grimes, Joseph E. 1972. Outlines and overlays. Language 48(3): 513-524.

Guillaume, Antoine. 2008. A Grammar of Cavineña. Berlin: Mouton de Gruyter.

Guillaume, Antoine. 2010. How ergative is Cavineña? In Ergativity in Amazonia [Typological Studies in Language 89], Spike Gildea \& Francesc Queixalós (eds), 97-120. Amsterdam: John Benjamin Publishing Company.

Hopper, Paul J. 1979. Aspect of foregrounding in discourse. In Discourse and Syntax, Talmy Givón (ed.), 213-241. New York NY: Academic Press.

van Kleef, Sjaak. 1988. Tail-head linkage in Siroi. Language and Linguistics in Melanesia 20: $147-156$.

Labov, William \& Waletzky, Joshua. 1967. Narrative analysis: oral versions of personal experience. In Essays on the Verbal and Visual Arts, June Helm (ed.), 12-42. Seattle WA: University of Washington Press.

Liccardi, Millicent R. 1983. Fonología cavineña: Palabras, grupos rítmicos y grupos fónicos. In Estudios sobre el Idioma Cavineña, Millicent R. Liccardi \& Elizabeth L. Camp (eds), 1-69. Cochabamba: Instituto Lingüístico de Verano.

Longacre, Robert E. 1968. Discourse, Paragraph, and Sentence Structure in Selected Philippine Languages, Vol. 1. Santa Ana CA: Summer Institute of Linguistics.

Loos, Eugene. 1963. Capanaha Narration Structure, Vol. I, supplement. University of Texas: Studies in Literature and language.

McKay, Graham. 2008. Cohesive features in Rembarrnga narratives. In Selected Papers from the 2007 Conference of the Australian Linguistic Society, T.J. Curnow (ed.). <http://www. als.asn.au/>

Oswalt, Robert L. 1976. Switch reference in Maiduan: An areal and typological contribution. International Journal of American Linguistics 42(4): 297-304.

Payne, Doris. 1992. Narrative discontinuity versus continuity in Yagua. Discourse Processes 15: 375-394. 
Seifart, Frank. 2010. The Bora connector pronoun and tail-head linkage: A study in languagespecific grammaticalization. Linguistics 48(4): 893-918.

Stirling, Lesley. 1993. Switch-Reference and Discourse Representation. Cambridge: CUP.

Stout, Mickey \& Thomson, Ruth. 1971. Kayapó narrative. International Journal of American Linguistics 37: 250-256.

Tavo Mayo, Victor. 1977. Yahua buricuare que. La tierra se partió. Riberalta: Instituto Lingüístico de Verano.

Thompson, Sandra A., Longacre, Robert E. \& Shin Ja J. Hwang. 2007. Adverbial clauses. In Language Typology and Syntactic Description, Vol. III: Complex Constructions, 2nd edn, Timothy Shopen (ed.), 237-300. Cambridge: CUP.

Thurman, Robert C. 1975. Chuave medial verbs. Anthropological Linguistics 17(7): 342-352.

Vanhove, Martine. 2005. Du lien entre propositions temporelles et anaphore en bedja. In Studi Afroasiatici. XI Incontro Italiano di Linguistica Camitosemitica, Allesandro Mengozzi (ed.), 153-166. Milano: Francoangeli.

de Vries, Lourens. 2005. Towards a typology of tail-head linkage in Papuan languages. Studies in Language 29(2): 363-384.

Waltz, Nathan \& Waltz, Carolyn. 1997. El Agua, la roca y el humo: Estudios sobre la cultura wanana de Vaupés. Santafé de Bogotá: Instituto Lingüístico de Verano.

\section{Appendix}

\section{Illustrative text}

This text was recorded by Antonio Yubanera in the traditional Cavineña community of Galilea in February 2001. Antonio Yubanera relates a story about a hunter who once saved a poor baby caiman that was lost in the forest and how later he was threatened by the same (then grown up) caiman, and how he was saved with the help of a witty dog. The recording runs for $3 \mathrm{~min} 35 \mathrm{sec}$. It was transcribed and translated with the assistance of Antonio Yubanera himself.

The text is divided into sentences, which are numbered from T1 to T51. In addition to the first two introductory sentences, I have only provided the morphological segmentation and glosses for the sentences that contain subordinate clauses of the three types described in detail in this paper. For the other sentences, I have only provided the free translation in English. The subordinate clauses that are repeated in THL constructions are in boldface; those that are not are underlined.

T1 Ekwita [babi-puji ju-kware=ke] kwatsabiji.

man hunt-NMLZ be-REM.PAST=LIG story

'The story of the man who had been a hunter.'

T2 Ju-kware =tu [peadya ekwita].

be-REM.PAST $=3 \mathrm{sg}$ one person

'There was a man.' 
T3 $B a b i=r a \quad k w a-k w a r e \quad e-k i k e=j u$.

hunt=PURP.MOT gO-REM.PAST NPF-forest=LOC

'He went hunting in the forest.'

T4 $[$ Babi=ra $\quad k w a-a t s u]=t u j a \quad=t u$

hunt=PURP.MOT go-SS $=3$ SG.DAT $=3 \mathrm{sG}$

tsuru-kware [peadya matuja].

meet-REM.PAST one caiman

'Going hunting, he met a (baby) caiman.'

T5 'He met him in the forest and on the ground.'

T6 Nereka-da, ashasha=piji [matuja jabakwa].

miserable-ASF small=DIM caiman baby_animal

'The baby caiman (lost in the middle of the forest) looked (lit. was) miserable and so small.'

(cd005)

T7 Tudya $=t u \quad$ ekwita $=r a \quad[$ nereka-da ba-atsu $]$

then $=3 \mathrm{sg}$ man=ERG miserable-AsF see-ss

[tuja shurumai=ju isha-tsu] duju-kware.

3sG.GeN bag=LOC put_in-ss transport-REM.PAST

'Feeling sorry for him (lit. seeing him miserable), the man put him in his bag and took him with him.'

T8 'Then he dropped him in a lake and the caiman lived.'

T9 'He lived and grew up.'

T10 [ $\underline{\text { Peadya }} \underline{\text { tunka }} \underline{\text { mara=kwana }} \underline{j u-a t s u}]=t u \quad$ ekwita one ten year=UNCERT be-ss $=3 \mathrm{sg}$ man

kwa-nuka-kware babi=ra [tuke amaka=nuka=dya].

gO-REITR-REM.PAST hunt=PURP.MOT $3 \mathrm{sG}$ side=REITR=FOC

'About ten years later, the man went hunting again, in the same area.'

(cd009)

T11 Tume $k w a-a t s u=t u j a \quad=t u \quad a-t i-k w a r e=d y a$

then go-ss $=3 \mathrm{SG}$.DAT $=3 \mathrm{sG}$ affect-GO-REM.PAST $=$ FOC

[umada ai [tura iye-kara $\underline{a-y a=k w a n a=k e]}$.

many INT 3sG.ERG kill-DESID affect-IMPFV $=\mathrm{PL}=$ LIG

'Having gone, he killed all (the animals) that he wanted to kill'.

T12 Tume $=t u$ jeti-nuka-ya=ke dyake chine=keja=kwita

then $=3 \mathrm{SG}$ come-REITR-IMPFV $=$ LIG very night $=$ LOC.GNL=RESTR

ju-diru-kware [bei jiruru].

be-GO-REM.PAST lake AT.EDGE.OF

'Then, as he was returning, he reached the shore of the lake very late at the end of the afternoon.' 
T13 'His house was very far. He had to go around the big lake.'

$(\mathrm{cd} 012)$

T14 Ladi=ke =tu peyainime ju-kware ekwita, dyake peyainime. thus=LIG $=3 \mathrm{SG}$ sad be-REM.PAST man very sad

'So he became worried, very worried.'

T15 Rike-taki=ama =tu bei ba-kware betsa-tsu.

cross-ABIL=NEG $=3 \mathrm{sg}$ lake see-REM.PAST swim-ss

'He felt that it would be impossible for him to cross the lake swimming.' (cd014)

T16 'In order to go around (the lake) it would be very far, and it was already late.'

T17 [[Jadya ju-atsu] tuke dyake peyainime ju-neti-ya=ju] thus be-ss 3sg very sad be-STAND-IMPFV=DS

$=t u \quad[$ matuja ebari] kwinana-kware [tuja $y$-akwa=ju].

$=3 \mathrm{sG}$ caiman big emerge-REM.PAST 3sG.GEN NPF-chest=LOC

'As he was (thinking) so and standing very worried, a big caiman appeared in front of him.'

T18 'He (the caiman) talked to him.'

T19 "You are a man and I feel very sad for you."

T20 “I will help you. I will do you a favor."

T21 "Ike =mira = $\varnothing \quad \underline{\text { maju=wie }=k e}=$ mira $=\varnothing \quad$ chachane-wa." $1 \mathrm{sG}=2 \mathrm{sG} . \mathrm{ERG}=1 \mathrm{sG} \quad \overline{\mathrm{die}=\mathrm{ANT}=\mathrm{LIG}}=2 \mathrm{SG} . \mathrm{ERG}=1 \mathrm{sG}$ cure-PERF "You saved me once I was about to die."

T22 "I will do you the same favor."

T23 [Jadya juatsu $]=$ tuja $=t u \quad k$-isaani-mere-ti-kware

thus be-sS $=3 \mathrm{SG}$.DAT $=3 \mathrm{SG}$ REF-ride-CAUS-REF-REM.PAST

[matuja ebari] pero eskupeta-ma.

caiman big but shotgun-without

'Having said so, he made him sit on top of him, but without his shotgun.'

T24 Eskupeta-ma =tuja =tu iya-tsura-kware [tuke dyake]. shotgun-without =3SG.DAT $=3 \mathrm{sg}$ put-GO_UP-REM.PAST $3 \mathrm{sg}$ ON 'Without his shotgun, he put him up on top of him.'

T25 [Tuke iya-tsura-tsu $]=t u \quad$ duju-kware=dya $\quad[$ bei patya $]$. 3SG put-GO_UP-SS $=3 \mathrm{SG}$ transport-REM.PAST=FOC lake IN.MIDDLE.OF 'He (the caiman) put him (the hunter) up on his back and carried him to the middle of the lake.'

(cd024) 
T26 [Bei patya duju jadya a-atsu $]=t u$

lake IN.MIDDLE.OF transport thus affect-ss $=3 \mathrm{sg}$

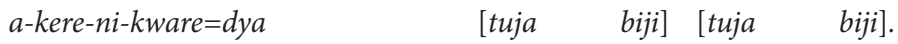

affect-CAUS.INVLT-REM.PAST $=$ FOC 3sG.GEN will 3sG.GEN will

'Carrying him this way to the middle of the lake, he conducted

(lit. affected) him according to his own (caiman's) will.'

T27 'He did not carry him properly to the other shore.'

T28 [Jadya ju-ya=ju] =tu ju-eti-kware,

thus be-IMPFV $=\mathrm{DS}=3 \mathrm{SG}$ be-COME-REM.PAST

iji-iji=ra kwa-kware juye, peadya.

drink-REDUP=PURP.MOT gO-REM.PAST OX one

'As he was doing so, an ox arrived, an ox went to drink, one ox.'

$(\operatorname{cd} 027)$

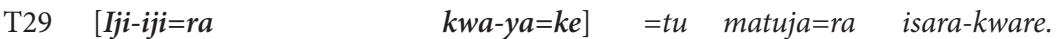

drink-REDUP=PURP.MOT go-IMPFV=LIG $=3 \mathrm{SG}$ caiman=ERG talk_to-REM.PAST

'As he was going to drink, the caiman talked to him.'

(cd028)

T30 "[Tata Juye], ejebucha $=m i$ mira adebaya

Mr. ox how =2SG 2sG.erg know-IMPFV

[jeeke ekwita [ike $\underline{\text { dyake=ke}]] ? " ~}$

this man $1 \mathrm{sg}$ ON=LIG

"Mr. ox, what do you think of this man who is on top of me?"

T31 "Should I go leave him on the solid ground, or not?"

T32 [Jadya ju-ya=ju] =tu juye=ra kemitsa-kware.

thus be-IMPFV $=\mathrm{DS} \quad=3 \mathrm{SG} \quad$ ox $=\mathrm{ERG}$ answer-REM.PAST

["Aijama" jadya] =tuja =tu a-kware juye=ra.

no thus $=3 \mathrm{SG} . \mathrm{DAT}=3 \mathrm{sG}$ affect-REM.PAST OX=ERG

'As he was saying so, the ox answered him. "No," the ox told him.'

T33 “No," he told him.'

T34 Amena [jadya ju-atsu $]^{25}=t u$ matuja ju-nuka-kware

вM thus be-ss $=3 \mathrm{sg}$ caiman be-REITR-REM.PAST

"aijama, iya-ti-ya=ama =pa =mike =era."

no put-GO-IMPFV=NEG =REP $=2 \mathrm{SG}=1$ SG.ERG

'As he (the ox) was saying so, the caiman said again, "no, I won't go and leave you"'.

25. The use of an SS-temporal clause here is unexpected since its subject is different from the subject of the main clause. 
T35 Jadya tura $a-y a=j u] \quad=t u \quad e k w i t a$

thus 3sG.ERG affect-IMPFV=DS $=3 \mathrm{sg}$ man

[dyake peyainime] ju-kware.

very sad be-REM.PAST

'When he (the caiman) told him so, the man became very worried.'

$(\operatorname{cd} 034)$

T36 [Dyake peyainime ju-ya=ju] =tu chapa ju-ti-nuka-kware.

very sad be-IMPFV $=$ DS $=3 \mathrm{sg}$ dog be-GO-REITR-REM.PAST

'As he was very worried, a dog arrived.'

T37 [ $\underline{\text { Peadya }}$ chapa $\underline{i j i-i j i-y a=j u}] \quad=t u$

one $\operatorname{dog}$ drink-REDUP-IMPFV=DS $=3 \mathrm{SG}$

matuja $=r a$ isara-nuka-kware.

caiman=ERG talk_to-REM.PAST

'As the dog was drinking, the caiman talked to him.'

$(\mathrm{cd} 036)$

T38 'You, Mr. dog, what do you think of this man on top of me?'

T39 "Should I leave him or not?"

T40 [Jadya ju-ya=ju] =tu chapa=ra a-kware

thus be-IMPFV $=$ DS $=3 \mathrm{SG} \quad$ dog $=$ ERG affect-REM.PAST

"aikwana je-nuka-kwe=piji rekeja ike isawe!"

FILL come-REITR-IMP=DIM around_here 1sG deaf

'As he was saying so, the dog told him "hm, come over here, I'm a bit deaf”'. (cd039)

T41 "Era =tu baka-ya=ama [ $\underline{\text { mira }}$ isara-ya=ke].

1sG.ERG $=3 \mathrm{sg}$ hear-IMPFV=NEG 2sG.ERG talk_to-IMPVF=LIG.

Je-nuka-kwe rekeja re-keja!"

come-REITR-IMP here-LOC.GNL here-LOC.GNL

"I don't hear what you are saying. Come a bit closer!"

$(\mathrm{cd} 040)$

T42 [Jadya ju-ya=ju] =tu matuja jipetana-kware.

thus be-IMPFV $=\mathrm{DS} \quad=3 \mathrm{SG}$ caiman move_closer-REM.PAST

'As he was saying so, the caiman went closer.'

T43 Jipetana-ya $=j u \quad=t u$ isara-nuka-kware.

move_closer-IMPFV=DS $=3 \mathrm{SG}$ talk_to-REITR-REM.PAST

'As he was moving closer, he (the fox) talked to him again.'

T44 He told him the same thing "no, I don’t hear you, keep coming a bit closer!" (cd043)

T45 [Jadya a-ya-ju $] \quad=t u$ jipetana-nuka-kware.

thus affect-IMPFV=DS $=3 \mathrm{SG}$ move_closer-REITR-REM.PAST

'When he told him so, he (the caiman) kept going closer.'

T46 Amena ekwita=ra ba-kware japa-dama uwa

putitana-kware.

BM man=ERG see-REM.PAST far-NEG solid_ground jump-REM.PAST

'Then, the man saw that the ground wasn't far anymore so he jumped.'

(cd045) 
T47 Putitana-tsu diru-kware.

jump-ss go-REM.PAST

'Having jumped he went away.'

(cd046)

T48 'And he arrived at his house'

(cd047)

T49 'This is how he saved himself.'

T50 'He first saved the caiman.'

(cd049)

T51 'Then the dog saved him. This is it.'

(cd050) 
